\title{
Genetic divergence among accessions of melon from traditional agriculture of the Brazilian Northeast
}

\author{
F.A.S. Aragão ${ }^{1}$, J. Torres Filho ${ }^{2}$, G.H.S. Nunes ${ }^{2}$, M.A. Queiróz ${ }^{3}$, P.N. Bordallo ${ }^{1}$, \\ G.S.C. Buso ${ }^{4}$, M.A. Ferreira ${ }^{4}$, Z.P. Costa ${ }^{1}$ and F. Bezerra Neto ${ }^{2}$ \\ ${ }^{1}$ Laboratório de Melhoramento e Recursos Genéticos Vegetais, \\ Embrapa Agroindústria Tropical, Fortaleza, CE, Brasil \\ ${ }^{2}$ Departamento de Ciências Vegetais, \\ Universidade Federal Rural do Semi-Árido, Mossoró, RN, Brasil \\ ${ }^{3}$ Departamento de Tecnologia e Ciências Sociais, \\ Universidade do Estado da Bahia, Juazeiro, BA, Brasil \\ ${ }^{4}$ Laboratório de Marcadores Moleculares, \\ Embrapa Recursos Genéticos e Biotecnologia, Brasília, DF, Brasil \\ Corresponding author: F.A.S. Aragão \\ E-mail: fernando.aragao@embrapa.br \\ Genet. Mol. Res. 12 (4): 6356-6371 (2013) \\ Received May 28, 2013 \\ Accepted November 1, 2013 \\ Published December 6, 2013 \\ DOI http://dx.doi.org/10.4238/2013.December.6.3
}

\begin{abstract}
The genetic divergence of 38 melon accessions from traditional agriculture of the Brazilian Northeast and three commercial hybrids were evaluated using fruit descriptors and microsatellite markers. The melon germplasm belongs to the botanic varieties cantalupensis (19), momordica (7), conomon (4), and inodorus (3), and to eight genotypes that were identified only at the species level. The fruit descriptors evaluated were: number of fruits per plant (NPF), fruit mass $(\mathrm{FM} ; \mathrm{kg})$, fruit longitudinal diameter ( $\mathrm{LD} ; \mathrm{cm})$, fruit transversal diameter (TD; $\mathrm{cm}$ ), shape index based on the LD/TD ratio, flesh pulp thickness, cavity thickness $(\mathrm{CT}$; $\mathrm{cm})$, firmness fruit pulp $(\mathrm{N})$, and soluble solids (SS; ${ }^{\circ}$ Brix). The results showed high variability for all
\end{abstract}


descriptors, especially for NPF, LD, and FM. The grouping analysis based on fruit descriptors produced eight groups without taxonomic criteria. The LD (22.52\%), NPF (19.70\%), CT (16.13\%), and SS (9.57\%) characteristics were the descriptors that contributed the most to genotype dissimilarity. The 17 simple sequence repeat polymorphic markers amplified 41 alleles with an average of 2.41 alleles and three genotypes per locus. Some markers presented a high frequency for the main allele. The genetic diversity ranged from 0.07 to 0.60 , the observed heterozygosity had very low values, and the mean polymorphism information content was 0.32 . Molecular genetic similarity analyses clustered the accessions in 13 groups, also not following taxonomic ranks. There was no association between morphoagronomic and molecular groupings. In conclusion, there was great variability among the accessions and among and within botanic groups.

Key words: Cucumis melo; Germplasm; Simple sequence repeat; Cluster; Descriptors

\section{INTRODUCTION}

The cultivated melon (Cucumis melo L., $2 \mathrm{n}=2 \mathrm{x}=24$ ) is a vegetable of great economic importance that is morphologically very different and belongs to the Cucurbitaceae family, which includes several other important crops such as cucumber, watermelon, pumpkin, and squash (Kirkbride, 1993). The current world production exceeds 28 million tons, with China being the main producing country, producing half of the world output, followed by Turkey, Iran, Spain, and the United States. In the last four decades, worldwide, melon production has increased by over $40 \%$ in each decade. In Brazil, the area planted expanded from 7.80 hectares in 1990 to 19,701 hectares in 2011 (FAO, 2013). In 2011, it produced 499,330 tons with a production value of US\$195 million, mainly concentrated in the Brazilian Northeast (95.8\%). In 2007, melon became the Brazil's most exported fruit, and Rio Grande do Norte and Ceará States were the largest producers and exporters.

The Brazilian Northeast has several cucurbit species, including melons, which were introduced centuries ago by slaves and immigrants. These species are widely cultivated by farmers in rain-fed small farms, resulting in several traditional cultivars (Queiróz, 1993). Thus, it is important to conserve this great allele reservoir. This germplasm needs to be characterized and evaluated to be managed and used properly.

The melon is a polymorphic species that is very variable in plant, leaf, flower, and fruit characteristics; it was initially divided into ten groups or botanical varieties by Naudin (1859) and was reclassified into seven vegetable groups by Munger and Robinson (1991). Two of them, cantalupensis and inodorus arouse great commercial interest, mainly due to their pulp taste (McCreight et al., 1993). Between these two groups of economic importance, there is great variation in the fruit morphology that allows them to be grouped into specific market types, such as: cantaloupe, galia, charentais (cantalupensis), yellow, piel de sapo, and honeydew (inodorus).

The assessment of genetic variability is important not only for the organization and preservation of genetic resources but also for practical applications, such as widening the ge- 
netic base and heterosis exploitation. Increasing the genetic base is a major concern in species in which the practice of inbreeding resulted in genetic diversity loss (Staub et al., 2000), a process that could be responsible for the lack of success in new hybrid combinations. Moreover, because heterosis is related to genetic divergence between parents, information about the genetic similarity between genotypes of agronomically important species can also facilitate the prediction of crosses that will produce hybrids with better performance.

This genetic diversity among individuals or populations can be determined by morphological and molecular markers. In this sense, phenotypic characteristics are not ideal markers because they are generally influenced by environmental factors and plant development stage; in some species, adequate levels of phenotypic polymorphism are not available (Bernet et al., 2003). However, morphological methods are essential to assess the genetic resources that are needed for initial diversity studies and to identify traditional cultivars (Konopka and Hanson, 1985). On the other hand, molecular markers are independent of environmental conditions and present high levels of polymorphism (Staub et al., 1996).

In the past decade, the use of molecular markers has enabled studies of DNA polymorphism for genetic mapping, marker assisted selection in plant breeding, research of genetic relatedness, phylogeny, and genetic divergence. Thus, molecular markers are tools that facilitate the study of various biological areas, such as cultivar identification, evolution and population genetics, and quantitative traits analysis in population genetics (Ritschel et al., 2004; Deleu et al., 2009; Fernández-Silva et al., 2009), with great opportunities for use in the genetic improvement of different crops, such as yardlong bean (Tantasawat et al., 2010), tomato (Mazzucato et al., 2010), and watermelon (Djé et al., 2010).

Among the markers, microsatellites allow wide use in breeding programs. The availability and abundance of these markers along the plant genome and their polymorphic and codominant nature based on polymerase chain reaction (PCR) enzyme makes them useful in studies of genetic diversity (Ferreira and Grattapaglia, 1998).

This research aimed to study the magnitude of genetic divergence among 38 accessions of melon from the Cucurbit Germplasm Bank of Northeast Brazil using fruit descriptors and simple sequence repeat (SSR) molecular markers.

\section{MATERIAL AND METHODS}

\section{Germplasm}

Thirty-eight accessions of melon from the Cucurbit Germplasm Bank of Northeast Brazil, located at Embrapa Semiárido in Petrolina, PE, and three commercial cultivars were evaluated. The germplasm was characterized morphoagronomically in the years 2006 and 2007, using descriptors published by IPGRI (2003), in the Universidade Federal Rural do Semi-Árido (UFERSA), Mossoró, RN.

\section{Obtaining plant material}

Ten seeds of each accession were planted in plastic trays of 150 cells that were filled with commercial substrate for germination (Plantmax ${ }^{\circledR}$, Brazil). Ten days after sowing, five seedlings were transplanted into five plastic pots with a capacity of $5 \mathrm{~L}$ that were filled with 
green coconut shell (50\% fiber and 50\% powder). Plants were fertirrigated daily with nutrient solution and were maintained for 20 days in the vase in order to get the leaf samples for DNA extraction. This step was carried out at a greenhouse of Embrapa Agroindústria Tropical, Fortaleza, CE, during the first half of 2009.

\section{Genomic DNA extraction}

Genomic DNA was extracted as proposed by Ferreira and Grattapaglia (1998), with some adjustments, at the Laboratory of Molecular Biology of Embrapa Agroindústria Tropical. Subsequently, all DNA was quantified using a Nanodrop ${ }^{\circledR} 2000$ spectrophotometer, which determines the concentration and purity of DNA. After the quantification, DNA was diluted to a concentration of $3 \mathrm{ng} / \mu \mathrm{L}$, which is appropriate for polymerase chain reaction (PCR).

\section{Amplification reactions, electrophoresis, and molecular data}

The amplification reactions contained a total volume of $25 \mu \mathrm{L}$ as follows: 0.25 $\mathrm{mM}$ dNTP, $0.3 \mathrm{mM}$ of each primer, PCR buffer (10 mM Tris-HCl, $\mathrm{pH} 9), 1.5 \mu \mathrm{M} \mathrm{MgCl}_{2}$, $1 \mathrm{U}$ Taq DNA polymerase, $10 \mathrm{ng}$ genomic DNA, and sterile ultrapure water. We used 25 polymorphic primers that were described by Ritschel et al. (2004), who developed SSR markers for melon.

The amplification program consisted of $4 \mathrm{~min}$ at $94^{\circ} \mathrm{C}$ for initial DNA denaturation; 30 cycles of DNA denaturation for $1 \mathrm{~min}$ at $94^{\circ} \mathrm{C}$, annealing for $1 \mathrm{~min}$ at $50^{\circ}-58^{\circ} \mathrm{C}$ (depending on the primer), and DNA amplification for $1 \mathrm{~min}$ at $72^{\circ} \mathrm{C}$; and a final extension step for 7 min at $72^{\circ} \mathrm{C}$. The PCR was performed in a model MJ Research PTC ${ }^{\circledR}$ thermal cycler.

The products of amplification were subjected to $4 \%$ polyacrylamide gels containing $7 \mathrm{M}$ urea in Tris, borate, ethylenediaminetetraacetic acid buffer. Electrophoresis was performed at $45 \mathrm{~W}$ of constant power, and gels were stained with silver nitrate. Molecular data were obtained from the visualization of bands, considering the polymorphic markers and their respective alleles, which were determined by the presence or absence of bands and by the sizes of DNA fragments at each locus.

The steps of amplification by PCR, electrophoresis, and the obtaining of molecular data were performed at the Laboratory of Molecular Markers of Embrapa Recursos Genéticos e Biotecnologia, Brasília, DF.

\section{Statistical analysis}

The morphoagronomic evaluation was performed using nine quantitative fruit descriptors: number of fruits per plant, fruit mass $(\mathrm{kg})$, longitudinal diameter of fruit (LD) $(\mathrm{mm})$ measured with a caliper, transverse diameter of the fruit (TD) (mm) measured with a caliper, shape index (LD/TD), flesh pulp thickness $(\mathrm{mm})$ measured with a caliper, cavity thickness $(\mathrm{mm})$ measured with a caliper, fruit pulp firmness $(\mathrm{N})$ measured with a penetrometer, and soluble solids $\left({ }^{\circ}\right.$ Brix) measured with a digital refractometer. For all characteristics, the mean of five fruits from different plants randomly chosen in the plot was considered. 
The mean and covariance matrices of residuals were estimated in which the genetic distances of accessions were also estimated based on the Mahalanobis distance as a measure of genetic distance, and the dendrogram was generated by the unweighted pair group method with arithmetic mean (UPGMA). The relative contribution of descriptors for genetic divergence was estimated by the method of Singh (1981).

The SSR loci characterizations were calculated as follows: 1) number and frequency of observations given by the number of genotypes with at least two alleles and the percentage of the total individuals studied; 2) number of alleles observed for each marker; 3) number of genotypes observed at each locus; 4) frequency of the predominant alleles; 5) genetic diversity, which is also known as expected heterozygosity; 6) observed heterozygosity; and 7) mean content of polymorphic information. Additionally, a matrix of genetic distances was generated by the method of Nei (1972), and the dendrogram was generated by the UPGMA method. For these procedures, the program PowerMarker ${ }^{\circledR}$ (Liu and Muse, 2005) was used.

The efficiency of both dendrograms derived from morphological and molecular genetic distances was assessed using the cophenetic correlation coefficient by the Mantel test, which notes the concordance between the original dissimilarity matrices and the UPGMA clustering. The overall average of the genetic distances between accessions in each dendrogram was considered as the cutoff point for grouping. All analyses were performed using the Genes software (Cruz, 2013).

\section{RESULTS AND DISCUSSION}

\section{Morphoagronomic genetic divergence}

A high variation in the color of skin and pulp was observed, with predominantly yellow peel, followed by white and green color, showing ample variability among accessions (Figure 1A and B). Accession A-39 (cantalupensis) had a cream-colored shell, while accession A-32 (momordica) has the shell of the gust type in green and yellow. As for the flesh color, most had a white color, followed by salmon and greenish-white colors, and three accessions had green-colored pulp. Escribano and Lázaro (2009) evaluated 28 accessions of melon that were collected in Spain, and they found great variation in pulp color and observed a second color in the pulp of some accessions.

The accessions differed in the number of fruits per plant, which was the most variable descriptor among those evaluated. Accessions A-16, A-17 (conomon), and A-15 (momordica) were the most prolific, with 11.4, 7.3, and 6.9 fruits per plant, respectively (Table 1). In a study of genetic divergence with strains of three botanical varieties of Cucumis, the authors found also a strain of the group momordica that had the highest number of fruits per plant (Paiva, 2002).

As for the average weight of the fruit, although A-32 (momordica) and A-12 (not set) also obtained fruit weighing up to $1.0 \mathrm{~kg}$, the plants with the highest average weight of fruit were predominantly from the botanical variety conomon (A-09, A-11, A-16, and A-17). Accessions A-34 (cantalupensis) and A-35 (not defined) were the only ones with an average fruit weight exceeding $2.0 \mathrm{~kg}$. Evaluating groups of accessions of melon from Hungary and Turkey, Szamosi et al. (2010) observed differences in fruit weight within each germplasm group; however, there were no significant differences between groups. 
In general, the accessions showed wide variability in index format, from oval to long, which reflected the variability found in the longitudinal and transverse diameters (Figure 1A). Extensive variation in length and width of the melon fruit has been observed in the literature (Stepansky et al., 1999; López-Sesé et al., 2003; Escribano and Lázaro, 2009; Szamosi et al., 2010). In addition, Monforte et al. (2005) found variations in the heterosis of the longitudinal and transverse diameter characteristics and fruit shape index while working with accessions from Africa, Asia, and Europe.
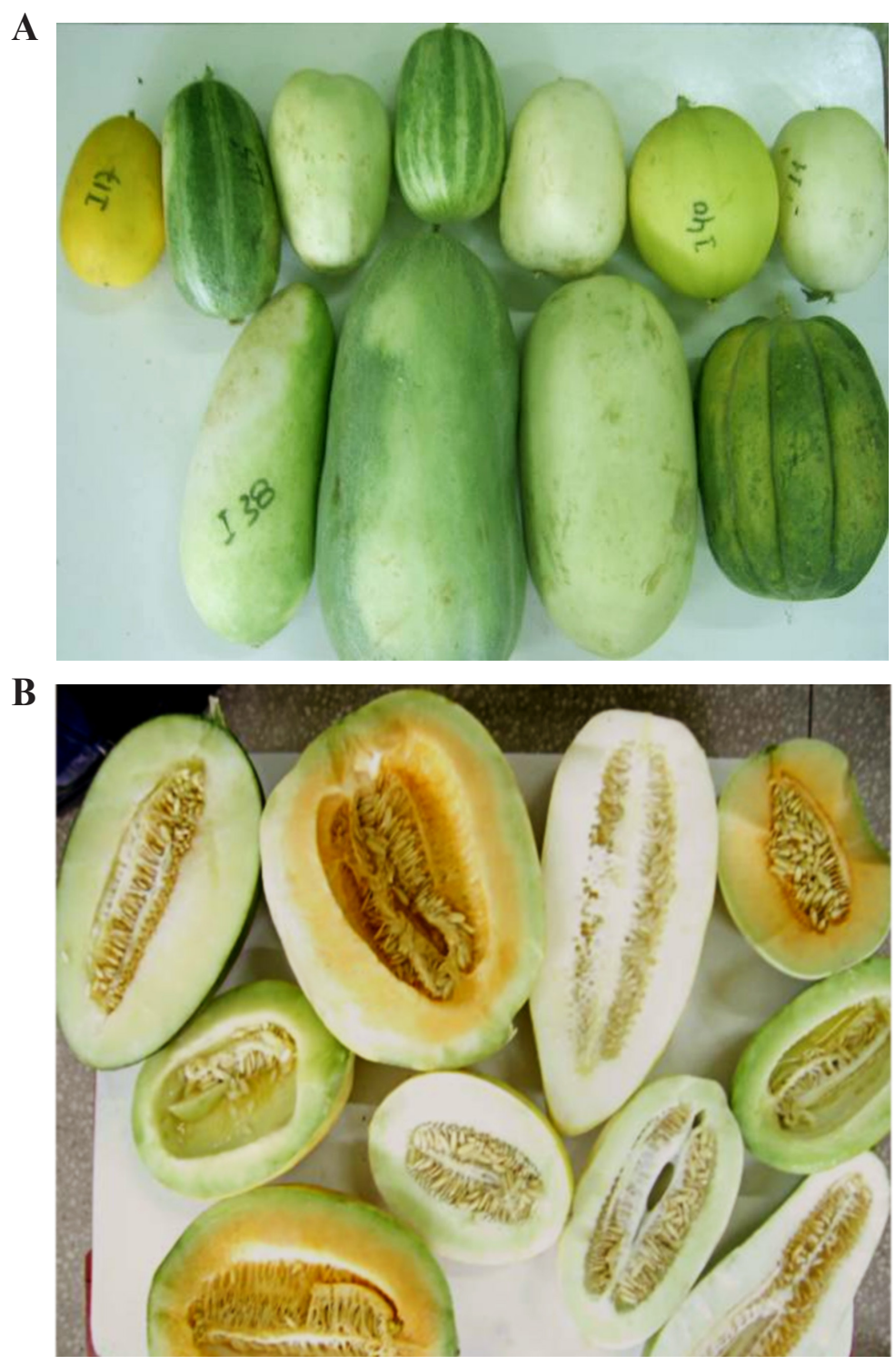

Figure 1. Variation in skin color and in pulp color of fruit of some accessions of melon from traditional agriculture of the Brazilian Northeast. 
Table 1. Descriptors of the fruits of the accessions/cultivars of melon characterized.

\begin{tabular}{|c|c|c|c|c|c|c|c|c|c|c|c|c|}
\hline Accessions & BG & $\mathrm{SC}$ & $\mathrm{PC}$ & NFP & FM & LD & TD & SI & FT & $\mathrm{CT}$ & $\mathrm{FF}$ & SS \\
\hline A. 01 & cantalupensis & $\mathrm{gr}$ & $\mathrm{sa}$ & 2.4 & 1.5 & 19.5 & 13.2 & 1.5 & 2.9 & 7.4 & 24.0 & 5.8 \\
\hline A. 02 & cantalupensis & ye & wh & 5.2 & 1.4 & 26.2 & 10.9 & 2.4 & 2.7 & 5.4 & 17.8 & 4.5 \\
\hline A. 03 & cantalupensis & $\mathrm{gr}$ & wg & 1.6 & 1.4 & 19.1 & 11.9 & 1.7 & 3.0 & 6.1 & 29.3 & 5.9 \\
\hline A. 04 & cantalupensis & ye & $\mathrm{sa}$ & 1.9 & 1.3 & 17.4 & 11.9 & 1.5 & 2.4 & 6.8 & 32.0 & 5.9 \\
\hline A. 05 & $\mathrm{Nd}$ & gr & wh & 4.0 & 1.3 & 21.0 & 10.4 & 2.0 & 2.7 & 5.2 & 18.2 & 5.4 \\
\hline A. 06 & cantalupensis & ye & $\mathrm{sa}$ & 1.5 & 1.8 & 21.5 & 12.7 & 1.7 & 3.2 & 6.3 & 23.6 & 6.0 \\
\hline A. 07 & cantalupensis & ye & $\mathrm{sa}$ & 2.4 & 1.3 & 18.5 & 11.9 & 1.6 & 3.0 & 5.7 & 22.7 & 6.5 \\
\hline A. 08 & $\mathrm{Nd}$ & wh & wh & 1.7 & 1.3 & 18.8 & 12.0 & 1.6 & 3.2 & 5.5 & 26.7 & 6.9 \\
\hline A. 09 & conomon & ye & wh & 4.0 & 0.6 & 16.1 & 8.4 & 1.9 & 2.2 & 4.5 & 23.1 & 5.8 \\
\hline A. 11 & conomon & wh & wh & 5.9 & 0.7 & 14.8 & 9.1 & 1.6 & 2.2 & 4.7 & 25.8 & 6.8 \\
\hline A. 12 & $\mathrm{Nd}$ & ye & wh & 4.7 & 0.6 & 16.0 & 8.4 & 2.0 & 2.0 & 4.5 & 28.0 & 5.9 \\
\hline A. 13 & cantalupensis & gr & gr & 2.3 & 1.0 & 16.4 & 10.6 & 1.5 & 2.3 & 6.0 & 35.1 & 6.5 \\
\hline A. 14 & cantalupensis & ye & wg & 1.6 & 1.5 & 20.0 & 12.5 & 1.7 & 2.6 & 7.0 & 22.2 & 6.2 \\
\hline A. 15 & momordica & wh & wh & 6.9 & 1.2 & 24.2 & 12.9 & 2.0 & 2.6 & 5.2 & 16.4 & 4.7 \\
\hline A. 16 & conomon & ye & wh & 11.4 & 0.4 & 11.6 & 7.6 & 1.5 & 2.0 & 3.7 & 40.9 & 4.1 \\
\hline A. 17 & conomon & ye & wh & 7.3 & 0.6 & 15.1 & 8.8 & 1.7 & 2.1 & 4.7 & 26.7 & 8.0 \\
\hline A. 18 & cantalupensis & ye & wh & 4.4 & 1.1 & 19.2 & 10.6 & 1.9 & 2.7 & 5.3 & 18.7 & 5.6 \\
\hline A. 19 & $\mathrm{Nd}$ & wh & wh & 2.2 & 1.6 & 15.0 & 13.3 & 1.1 & 3.4 & 6.4 & 20.0 & 6.7 \\
\hline A. 22 & cantalupensis & gr & $\mathrm{gr}$ & 2.0 & 1.5 & 20.8 & 11.9 & 1.8 & 2.9 & 6.0 & 23.1 & 6.3 \\
\hline A. 23 & momordica & wh & wh & 4.8 & 1.1 & 22.3 & 10.5 & 2.1 & 2.3 & 6.0 & 30.7 & 6.1 \\
\hline A. 24 & cantalupensis & ye & $\mathrm{sa}$ & 3.2 & 1.1 & 21.0 & 10.8 & 1.9 & 2.6 & 5.5 & 26.7 & 6.7 \\
\hline A. 25 & cantalupensis & ye & sa & 1.6 & 1.9 & 20.1 & 13.4 & 1.6 & 3.0 & 7.3 & 18.7 & 6.6 \\
\hline A. 26 & $\mathrm{Nd}$ & wh & wh & 2.2 & 1.9 & 22.4 & 13.5 & 1.7 & 3.5 & 6.6 & 17.3 & 6.6 \\
\hline A. 27 & $\mathrm{Nd}$ & wh & $\mathrm{sa}$ & 1.9 & 1.6 & 19.9 & 9.6 & 1.6 & 2.5 & 4.4 & 16.4 & 3.8 \\
\hline A. 28 & cantalupensis & gr & sa & 2.3 & 1.8 & 23.9 & 13.1 & 1.8 & 5.6 & 6.9 & 32.0 & 6.5 \\
\hline A. 29 & cantalupensis & gr & wg & 4.1 & 1.1 & 17.7 & 10.9 & 1.6 & 2.5 & 5.8 & 27.1 & 7.3 \\
\hline A. 30 & momordica & wh & wh & 1.9 & 1.9 & 19.5 & 13.7 & 1.5 & 3.0 & 7.0 & 21.3 & 6.3 \\
\hline A. 31 & cantalupensis & ye & gr & 4.3 & 1.3 & 23.6 & 11.2 & 2.1 & 2.5 & 6.0 & 19.6 & 5.0 \\
\hline A. 32 & momordica & $\mathrm{gu}$ & wh & 6.7 & 0.7 & 15.5 & 9.3 & 1.6 & 2.1 & 5.1 & 21.3 & 7.4 \\
\hline A. 33 & $\mathrm{Nd}$ & ye & wh & 2.2 & 1.7 & 20.0 & 13.4 & 1.5 & 2.5 & 8.4 & 28.0 & 6.1 \\
\hline A. 34 & cantalupensis & ye & sa & 0.9 & 2.1 & 21.2 & 15.2 & 1.4 & 3.2 & 9.0 & 24.0 & 6.1 \\
\hline A. 35 & $\mathrm{Nd}$ & $\mathrm{gr}$ & sa & 3.2 & 2.4 & 30.2 & 13.6 & 2.3 & 3.3 & 6.9 & 21.8 & 4.9 \\
\hline A. 36 & cantalupensis & gr & wh & 4.8 & 1.6 & 27.8 & 11.1 & 2.5 & 2.9 & 5.2 & 24.0 & 3.5 \\
\hline A. 37 & momordica & wh & wh & 3.8 & 1.0 & 17.7 & 10.8 & 1.6 & 2.9 & 5.2 & 25.8 & 6.2 \\
\hline A. 38 & momordica & $\mathrm{gr}$ & wh & 4.5 & 1.3 & 24.0 & 10.5 & 2.3 & 2.7 & 5.1 & 17.8 & 4.2 \\
\hline A. 39 & cantalupensis & $\mathrm{cr}$ & wh & 4.2 & 1.0 & 23.6 & 9.6 & 2.5 & 2.2 & 5.0 & 24.0 & 3.3 \\
\hline A. 41 & cantalupensis & wh & wh & 1.8 & 1.2 & 15.6 & 12.6 & 1.3 & 3.5 & 5.7 & 21.8 & 7.1 \\
\hline A. 42 & momordica & wh & wh & 2.7 & 1.6 & 22.7 & 12.3 & 1.9 & 2.8 & 6.5 & 20.4 & 5.7 \\
\hline A.43 - 'HDRF' & inodorus & wh & $\mathrm{sa}$ & 1.3 & 1.1 & 13.3 & 12.2 & 1.1 & 3.4 & 5.2 & 36.9 & 10.1 \\
\hline A.44 - 'Mandacaru' & inodorus & ye & wh & 1.6 & 1.4 & 15.4 & 13.6 & 1.1 & 3.8 & 5.8 & 35.1 & 8.5 \\
\hline A.45 - 'Vereda' & inodorus & ye & wh & 1.5 & 1.3 & 15.9 & 10.4 & 2.0 & 3.7 & 5.9 & 24.0 & 8.1 \\
\hline Maximum & & & & 13.3 & 4.1 & 34.0 & 21.3 & 4.3 & 12.8 & 10.7 & 13.0 & 11.6 \\
\hline Minimum & & & & 0.3 & 0.3 & 10.8 & 3.8 & 0.9 & 1.7 & 3.5 & 1.4 & 2.8 \\
\hline CV $(\%)$ & & & & 62.4 & 34.1 & 38.8 & 21.5 & 15.6 & 28.3 & 21.7 & 22.9 & 23.3 \\
\hline
\end{tabular}

$\mathrm{Nd}=$ not defined; $\mathrm{gr}=$ green; ye = yellow; $w h=$ white; $\mathrm{gu}=$ gust; $\mathrm{cr}=$ cream; $\mathrm{sa}=$ salmon; $\mathrm{wg}=$ white-green; $\mathrm{BG}$ $=$ botanical group; $\mathrm{SC}=$ skin color; $\mathrm{PC}=$ pulp color; $\mathrm{NFP}=$ No. of fruits per plant; $\mathrm{FM}=$ fruit mass $(\mathrm{kg}) ; \mathrm{LD}=$ longitudinal diameter of fruit $(\mathrm{cm}) ; \mathrm{TD}=$ transverse diameter of fruit $(\mathrm{cm}) ; \mathrm{SI}=$ shape index $(\mathrm{LD} / \mathrm{TD}) ; \mathrm{FT}=$ flesh pulp thickness $(\mathrm{cm}) ; \mathrm{CT}=$ cavity thickness $(\mathrm{cm}) ; \mathrm{FF}=$ firmness fruit pulp $(\mathrm{N})$ and $\mathrm{SS}=$ soluble solids $\left({ }^{\circ} \mathrm{Brix}\right)$.

Accessions also varied in pulp thickness, with an amplitude of $4.3 \mathrm{~cm}$ and an absolute highlight for accession A-28 (cantalupensis), which had a pulp thickness over $5 \mathrm{~cm}$. Conversely, accessions A-12 (not set) and A-16 (conomon) had the lowest average pulp thickness, with only $2.0 \mathrm{~cm}$ of pulp.

As for the thickness of the cavity, accessions A-16 and A-27 (not defined) had the lowest average scores, 3.7 and 4.4, respectively. Accessions A-33 (not defined) and A-34 (cantalupensis) had the highest average, which was at least $8.4 \mathrm{~cm}$. In contrast, Paris et al. (2008) observed no significant differences in the thickness of the cavity in lineages and families, even from contrasting parents. 
Accessions A-04, A-13, A-28 (cantalupensis), A-16 (conomon), A-43, and A-44 (inodorus) showed firmness above $30 \mathrm{~N}$, and the lowest values were observed in accessions A-15 (momordica) and A-27 (not defined), which had an average of 16.4 N. Accessions showed very low values for soluble solids, for which the estimates ranged from 3.3 to 8.0 ${ }^{\circ}$ Brix; this was unlike the observation for hybrids, which had values above $8.0^{\circ}$ Brix. Similar results were observed by Monforte et al. (2005) and Szamosi et al. (2010). However, they found lower values than Hosoki et al. (1990) and López-Sesé et al. (2003). Different results for melon fruit soluble solids are associated with the quantitative nature of this characteristic (Monforte et al., 2004), which is strongly influenced by the environment.

Therefore, the characterization of the accessions based on descriptors of the fruit (Table 1) showed great variability, even within the same botanical group, which is consistent with reports of polymorphisms of Cucumis melo (Staub et al., 2004; Nakata et al., 2005; Escribano and Lázaro, 2009). It is noteworthy that these morphological methods, which are the basis for traditional systematics, are irreplaceable in the evaluation of genetic resources and are necessary for initial assessment of diversity and precise identification of traditional cultivars (Konopka and Hanson, 1985).

The cluster analysis of the fruit descriptors formed eight groups of accessions (Figure 2). In the first group, the predominant variety was cantalupensis and included A-01, A-14, A-25, A-03, A-07, A-22, A-06, A-04, A-13, and A-41 (cantalupensis); A-30 and A-42 (momordica); A-45 (inodorus); and A-08, A-26, and A-19 (not defined). The second group included only accession A-28 (cantalupensis), which stood out for its high pulp thickness. The third group included accessions A-33 (not defined) and A-34 (cantalupensis), which presented the worst cavities, averaging over $8 \mathrm{~cm}$. As for the botanical groups of Cucumis melo, the fourth group was the most heterogeneous and included accessions A-18, A-24, and A-29 (cantalupensis); A-09, A-11, and A-17 (conomon); A-32 and A-37 (momordica); and A-05 and A-12 (not defined). In the fifth group, two commercial hybrids, A-43 (HDRF) and A-44 (Mandacaru), were incorporated that were both of the botanical variety inodorus. The sixth group included mostly plants of the variety cantalupensis; it included seven genotypes: A-02, A-31, A-36, and A-39 (cantalupensis); A-15 and A-38 (momordica); and A-35 (not defined). The seventh group involved only accession A-27 (not defined), which stood out as having the least firm pulp, the best second cavity, and a low content of soluble solids. Finally, the eight group included accession A-16 (conomon), which stood out for its high prolificacy and high firmness.

The lack of consistency observed in the clustering of accessions from the same botanical group in this study is similar to the results of Escribano and Lázaro (2009), and it is associated with the quantitative nature of characteristics because of environmental influence. Moreover, morphological descriptors divided 29 accessions of melon including inodorus, flexuosus, and dudaim varieties into eight groups without an association with the taxonomic type (Soltani et al., 2010).

The clustering dendrogram (Figure 2) obtained a cophenetic value of 0.70 , which was considered high because an $r$ value above 0.56 is considered to reflect agreement with the values of genetic similarity (Cruz and Carneiro, 2003).

The analysis of the relative contribution of each descriptor for the expression of genetic diversity by means of the method of Singh (1981) indicated that the lateral diameter $(22.52 \%)$, number of fruits per plant $(19.70 \%)$, thickness of cavity $(16.13 \%)$, and soluble solids $(9.57 \%)$ were the descriptors that contributed most to the divergence among the 41 genotypes of melon assessed, explaining $70.61 \%$ of the total dissimilarity (Table 2). 


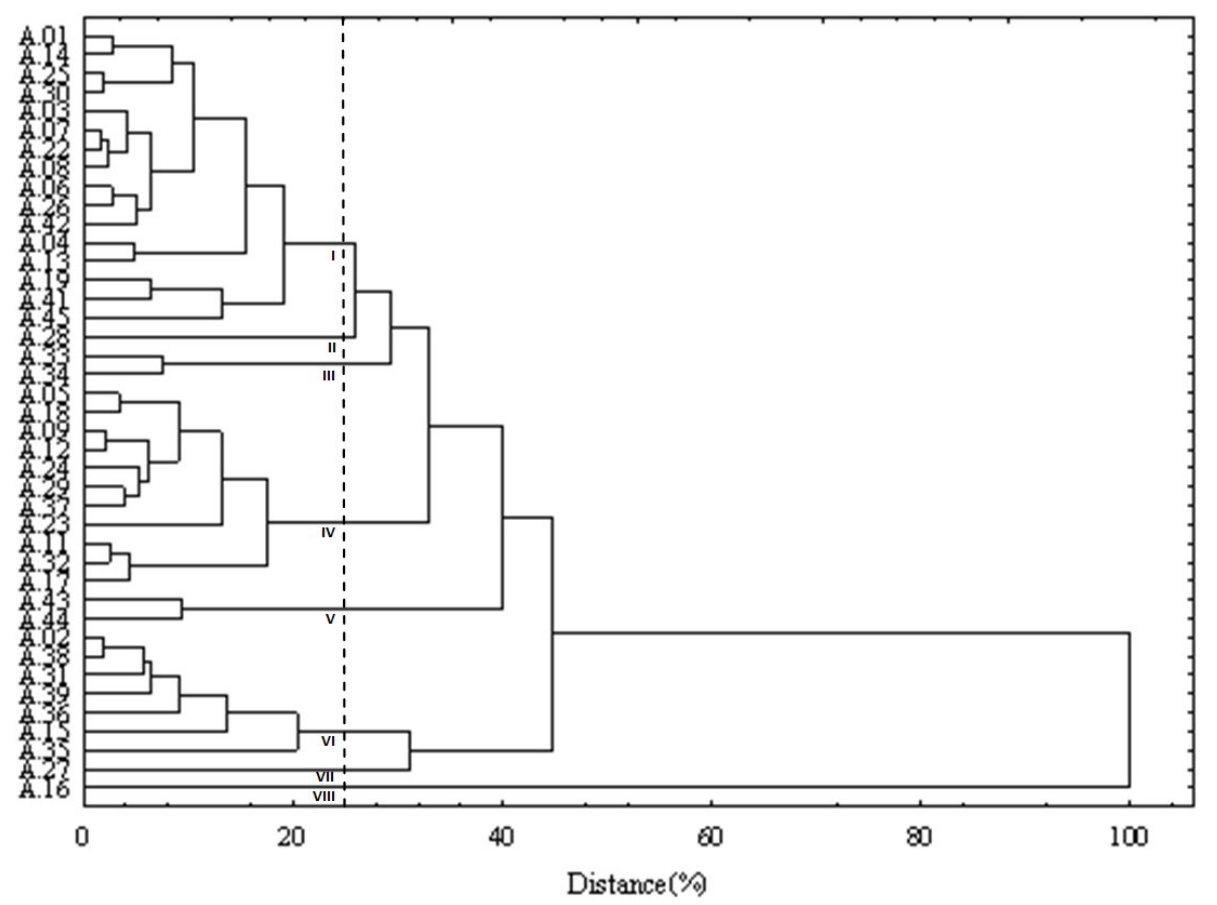

Figure 2. Cluster analysis of 41 melon genotypes by descriptors of fruit calculated by the unweighted paired group method with arithmetic means (UPGMA) clustering method using Mahalanobis distance.

Table 2. Estimates of the relative contribution of each characteristic for diversity (S.j) by the method of Singh, using the generalized Mahalanobis distances.

\begin{tabular}{lcc}
\hline Characteristics & S.j & Relative contribution (\%) \\
\hline LD & 6129.62 & 22.52 \\
NFP & 5363.29 & 19.70 \\
CT & 4391.37 & 16.13 \\
SS & 2604.79 & 9.57 \\
TD & 2410.77 & 8.86 \\
FMM & 2207.09 & 8.11 \\
PF & 1879.26 & 6.90 \\
SI & 1542.75 & 5.67 \\
PT & 690.69 & 2.54 \\
& Total & 100.00 \\
\hline
\end{tabular}

$\mathrm{LD}=$ longitudinal diameter of fruit $(\mathrm{cm}) ; \mathrm{NFP}=$ No. of fruits per plant; $\mathrm{CT}=$ cavity thickness $(\mathrm{cm}) ; \mathrm{SS}=$ soluble solids $\left({ }^{\circ}\right.$ Brix $) ; \mathrm{TD}=$ transverse diameter of fruit $(\mathrm{cm}) ; \mathrm{FMM}=$ fruit mean mass $(\mathrm{kg}) ; \mathrm{PF}=$ pulp firmness $(\mathrm{N})$; $\mathrm{SI}=$ shape index (LD/TD); PT = pulp thickness (cm).

The lateral diameter and number of fruits per plant showed high coefficients of variation. Although the thicknesses of the cavity and the soluble solids have many values around the mean, the extremes covered a wide range. In a study of genetic divergence with strains of melons of the botanical groups cantalupensis, inodorus, and momordica, soluble solids was also one of the characteristics that contributed most to the differentiation of genotypes (Paiva, 2002).

In the case of the melon crop, the most important descriptors are those related to production and fruit quality. The ideal cultivar of this cucurbit must have at least high productivity 
(over 25 tons/ha), fruit size appropriate to the market preferences for each type of melon, high pulp firmness, characteristics related to the time of shelf-life post-harvest, and high content of soluble solids, which is the main descriptor of the quality of melon (Nunes et al., 2006). A wide variation was observed within and among the identified botanic groups, which allows progress in melon breeding for the characteristic of fruit quality.

\section{Molecular genetic divergence}

Among the 25 microsatellite primers used, 17 were polymorphic for the group of evaluated genotypes, which can be considered a high percentage. Szabó et al. (2005), for example, detected polymorphism in only eight of 20 microsatellite markers evaluated. However, this high level of polymorphism of the markers was expected given that they were chosen among the polymorphic markers that were developed in the study of Ritschel et al. (2004), who developed SSR primers for melon. Important information about the 17 microsatellite primers such as repetitive unit, type, forward and reverse sequences, annealing temperature, and expected size of the fragment are shown in Table 3.

Table 3. Microsatellite locus, domain, types of repeats, sequence repeated, annealing temperature, and expected size of the fragment (in bp) of the 17 polymorphic microsatellite markers for the 41 genotypes evaluated.

\begin{tabular}{|c|c|c|c|c|c|}
\hline SSR marker & Repeating unit & Type $^{1}$ & Sequence forward and reverse & $\mathrm{Ta}\left({ }^{\circ} \mathrm{C}\right)$ & $\begin{array}{l}\text { Expected size } \\
\quad(\mathrm{bp})\end{array}$ \\
\hline CMBR7 & $(\mathrm{AG})_{30}$ & $P$ & $\begin{array}{l}\text { 5'-AAAATGAATGGGAGTGCGTG-3' } \\
\text { 5'-GCCTTCCTTTTCACCATCAA-3' }\end{array}$ & 60 & 122 \\
\hline CMBR12 & $(\mathrm{TC})_{15}$ & $P$ & $\begin{array}{l}\text { 5'-AAACAAACATGGAAATAGCTTTCA-3' } \\
\text { 5'-GCCTTTTGTGATGCTCCAAT-3' }\end{array}$ & 60 & 134 \\
\hline CMBR21 & $(\mathrm{TC})_{31}$ & $P$ & $\begin{array}{l}\text { 5'-AGATTCTGGTTGTTGGGCAG-3' } \\
\text { 5'-CAGCGATGATCAACAGAAACA-3' }\end{array}$ & 59 & 230 \\
\hline CMBR27 & $(\mathrm{TA})_{3}(\mathrm{TC})_{16}$ & $\mathrm{CP}$ & $\begin{array}{l}\text { 5'-AAACAAACATGGAAATAGCTTTCA-3' } \\
\text { 5'-TAGTTGGGTGGGCTAAAGGA-3' }\end{array}$ & 58 & 242 \\
\hline CMBR40 & $(\mathrm{CT})_{15} \mathrm{~T}_{3} \mathrm{CT}_{2}(\mathrm{CT})_{2}$ & $\mathrm{C}$ & $\begin{array}{l}\text { 5'-CGACAATCACGGGAGAGTTT-3' } \\
\text { 5'-TTGTTGCATCAAACTAACACAATC-3' }\end{array}$ & 56 & 153 \\
\hline CMBR56 & $(\mathrm{CT})_{3} \mathrm{~N}_{2}(\mathrm{CT})_{12}(\mathrm{CCCT})_{2} \mathrm{~N}_{8}(\mathrm{CT})_{3}(\mathrm{AT})_{3} \mathrm{~N}_{3}(\mathrm{TC})_{2}$ & $\mathrm{C}$ & $\begin{array}{l}\text { 5'-ACCCCAGCAGATGAACAAAC-3' } \\
\text { 5'-CAACGTTATGGGGATGAAGG-3' }\end{array}$ & 58 & 138 \\
\hline CMBR64 & $(\mathrm{CT})_{24}$ & $P$ & $\begin{array}{l}\text { 5'-ATACAGCAGATCCACAGGGG-3' } \\
\text { 5'-ATGGGAGTGTGTGGGATGTA-3' }\end{array}$ & 54 & 160 \\
\hline CMBR83 & $(\mathrm{GA})_{21}(\mathrm{CA})(\mathrm{GA})_{2}$ & $\mathrm{C}$ & $\begin{array}{l}\text { 5'-CGGACAAATCCCTCTCTGAA-3' } \\
\text { 5'-GAACAAGCAGCCAAAGACG-3' }\end{array}$ & 56 & 142 \\
\hline CMBR90 & $(\mathrm{CT})_{3}(\mathrm{CCG})_{2}(\mathrm{CT}) \mathrm{N}_{3}(\mathrm{TC})(\mathrm{CT}) \mathrm{N}_{14}(\mathrm{CT})$ & $\mathrm{C}$ & $\begin{array}{l}\text { 5'-GTACCTCCGCCGTTGATCT-3' } \\
\text { 5'-TGAGATAATAAGAAATCCAACCCA-3' }\end{array}$ & 56 & 147 \\
\hline CMBR92 & $(\mathrm{TA}) \mathrm{N}(\mathrm{TA})_{2} \mathrm{~N}_{6}(\mathrm{CT})_{15} \mathrm{~N}_{5}(\mathrm{TG})_{2}$ & $\mathrm{C}$ & $\begin{array}{l}\text { 5'-CAAACATGGAAATAGCTTTCATT-3' } \\
\text { 5'-GGTGGGCTAAAGGAACTTTCA-3' }\end{array}$ & 54 & 232 \\
\hline CMBR95 & $(\mathrm{CT}) \mathrm{N}(\mathrm{CT})_{2} \mathrm{~N}_{2}(\mathrm{CT})_{21}$ & $\mathrm{C}$ & $\begin{array}{l}\text { 5'-TTGACCTTTTACGGTGGTCC-3' } \\
\text { 5'-CGGACAAATCCCTCTCTGAA-3' }\end{array}$ & 56 & 117 \\
\hline CMBR100 & $(\mathrm{TC})_{20} \mathrm{~N}_{14}(\mathrm{TC})_{3}(\mathrm{TA})_{4} \mathrm{~N}_{2}(\mathrm{TC})_{2}$ & $\mathrm{C}$ & $\begin{array}{l}\text { 5'-GGACCAAACCAAACCCATTA-3' } \\
\text { 5'-ATGGGGATGAAGGGAGAAAG-3' }\end{array}$ & 56 & 126 \\
\hline CMBR105 & $(\mathrm{CT})_{12} \mathrm{C}(\mathrm{CCCT})_{2}(\mathrm{CT})(\mathrm{CCCT})$ & $\mathrm{CP}$ & $\begin{array}{l}\text { 5'-TGGTAAGCATTTTGAAATCACTTTT-3' } \\
\text { 5'-TTTGTATGGTTGGAGGGGAA-3' }\end{array}$ & 56 & 139 \\
\hline CMBR115 & $(\mathrm{CT})_{24}$ & $\mathrm{P}$ & $\begin{array}{l}\text { 5'-AGGGTGGAAAGACCCCTATG-3' } \\
\text { 5'-TGTGAATGTATCTTTTCTGATACTGC-3' }\end{array}$ & 52 & 151 \\
\hline CMBR140 & $(\mathrm{CT})_{27}(\mathrm{CA})_{2}$ & $\mathrm{CP}$ & $\begin{array}{l}\text { 5'-TGGTCATCTGATTGATTGGGTA-3' } \\
\text { 5'-TCACAAGGAAAAGAAAAAGACC-3' }\end{array}$ & 56 & 193 \\
\hline M176 & $(\mathrm{GA})_{12}$ & $\mathrm{P}$ & $\begin{array}{l}\text { 5'-TCACCAAACCCTAACACACAA-3' } \\
\text { 5'-TGGGGATATTCGGATGAAAA-3' }\end{array}$ & - & 109 \\
\hline CM254 & $(\mathrm{TC})_{21}$ & $\mathrm{P}$ & $\begin{array}{l}\text { 5'-ACCAAATAGCCCCAAATGTT-3' } \\
\text { 5'-TACAGACACGCCTTCACCTG-3' }\end{array}$ & - & 106 \\
\hline
\end{tabular}

${ }^{1}$ Repeats of the microsatellite marker. $\mathrm{C}=$ compost; $\mathrm{P}=$ perfect; $\mathrm{Ta}=$ annealing temperature of the primer in $\mathrm{PCR}$. 
The 17 primer pairs amplified 41 polymorphic fragments in the accessions/cultivars evaluated, with an average of 2.41 alleles and three genotypes per locus SSR, which is low when compared to the study by Szabó et al. (2005) that evaluated 47 accessions with eight SSR markers and amplified 40 microsatellite alleles. From the group of polymorphic markers, only six had two alleles and two genotypes. Although it may be considered low, the number of alleles per locus was higher than that found by López-Sesé et al. (2002), who amplified 23 alleles from eight SSR polymorphic markers.

Staub et al. (2000), comparing melon accessions from different botanical groups (cantalupensis, inodorus, conomon, and flexuosus), used 17 SSR markers, of which only seven were polymorphic, but they amplified 54 alleles. In addition, 93 alleles were detected in a trial that assessed the divergence of 40 melon accessions (cantalupensis, inodorus, and conomon), using 25 microsatellite markers (Ritschel et al., 2004).

For the markers CMBR64, CMBR100, and CMBR105, the frequency of the primary allele was over $90 \%$, reducing the informative power of the marker because they showed the lowest polymorphism information content (PIC) values, $0.09,0.16$, and 0.07 , respectively. The low number of alleles favors the establishment or fixation of a given allele in the population (Falconer, 1981).

Furthermore, genetic diversity, also called the expected heterozygosity, ranged from 0.07 at marker CMBR105 to 0.60 at marker CMBR83 (Figure 3A), averaging 0.40. Thus, because these values represent the probability that two randomly chosen alleles are different, low levels of homozygosity would be expected among accessions.
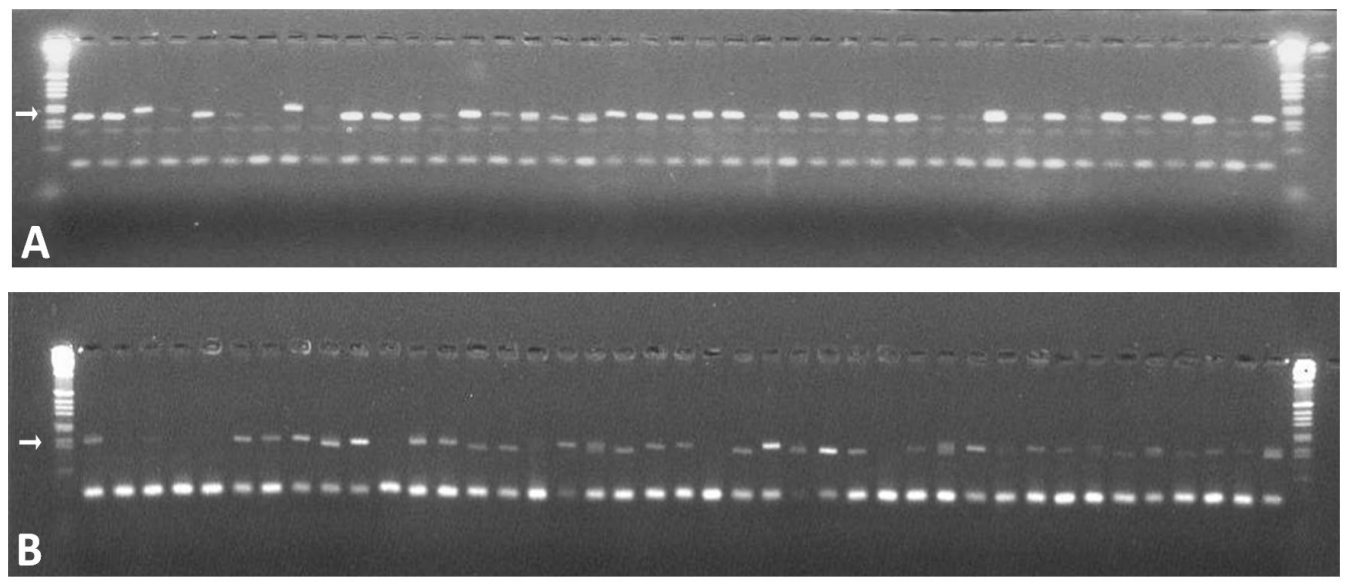

Figure 3. Gels of electrophoresis relating to the CMBR83 (A) and CMBR140 (B) markers.

However, heterozygosity, which expresses the percentage of heterozygous individuals, was very low, ranging from zero for markers CMBR12, CMBR21, CMBR92, and CMBR176 to 0.29 at marker CMBR56, averaging only 0.09 . These low values are associated with the low number of alleles observed (Table 4). Besides, in some genotypes, all identified alleles were in homozygosis. 


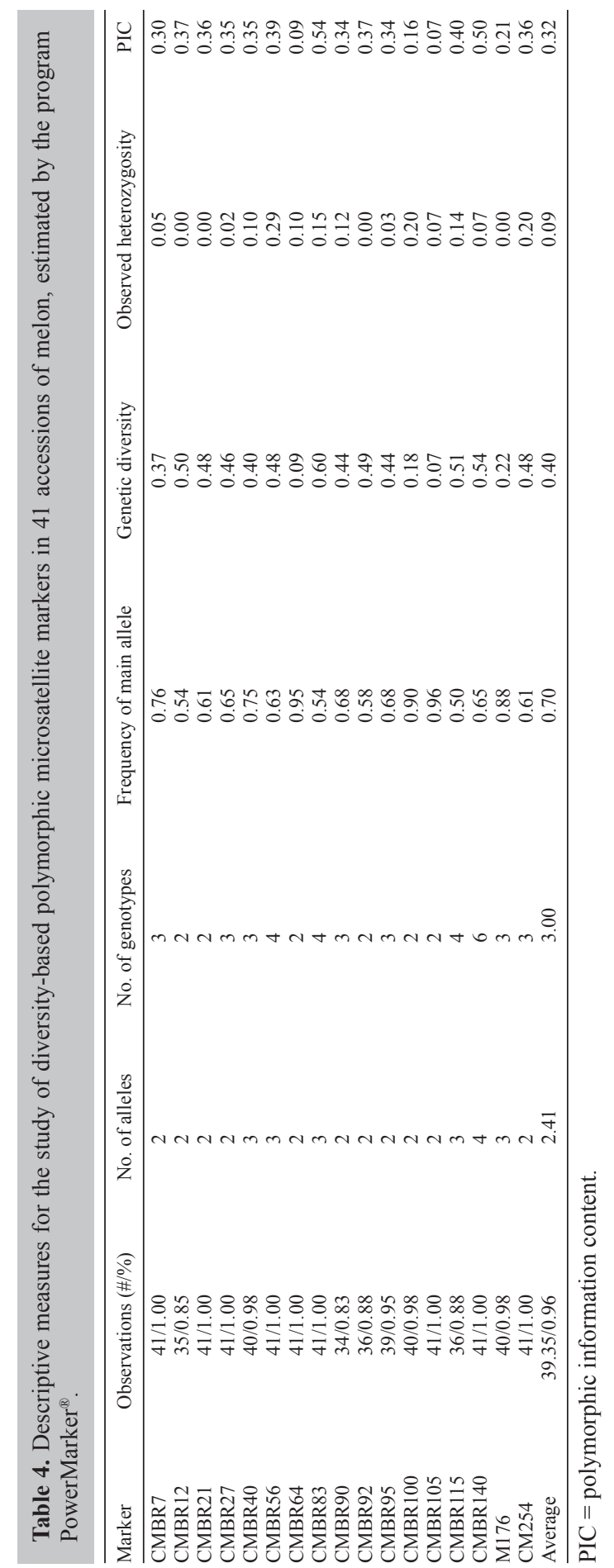


Given the origin of the accessions, the association of the high average frequency of the major alleles with low expected heterozygosity and many loci in homozygosity indicates that the multiplication of evaluated accessions before collecting altered the allelic frequencies, leading them to homozygosity.

The PIC value, which provides an estimate of the discriminatory power of the marker ranged from 0.07 at CMBR105 to 0.54 at CMBR83, averaging 0.32. CMBR140 (Figure 3B) had the highest number of alleles and genotypes and was also very informative, showing an average PIC of 0.50 . As advocated by López-Sesé et al. (2003), PIC values become close to the values of genetic diversity as the number of alleles of the SSR locus increases. Therefore, the discriminatory power of the marker is associated with both the frequency and number of alleles of the same marker. Additionally, the correlation between the number of alleles and PIC was calculated and estimated to be $0.50(\mathrm{P}<0.04)$, indicating that markers with a higher number of alleles have a higher discriminatory power for the evaluated genotypes.

The similarity analysis by means of the 17 polymorphic microsatellite markers separated the accessions into 13 groups (Figure 4). Among the groups, six groups included one accession each: A-01 (cantalupensis), A-28 (cantalupensis), A-35 (not defined), A-43 (inodorus), A-09 (conomon), and A-08 (not defined). One group included only two genotypes, A-44 and A-45 (inodorus), which are both hybrids.

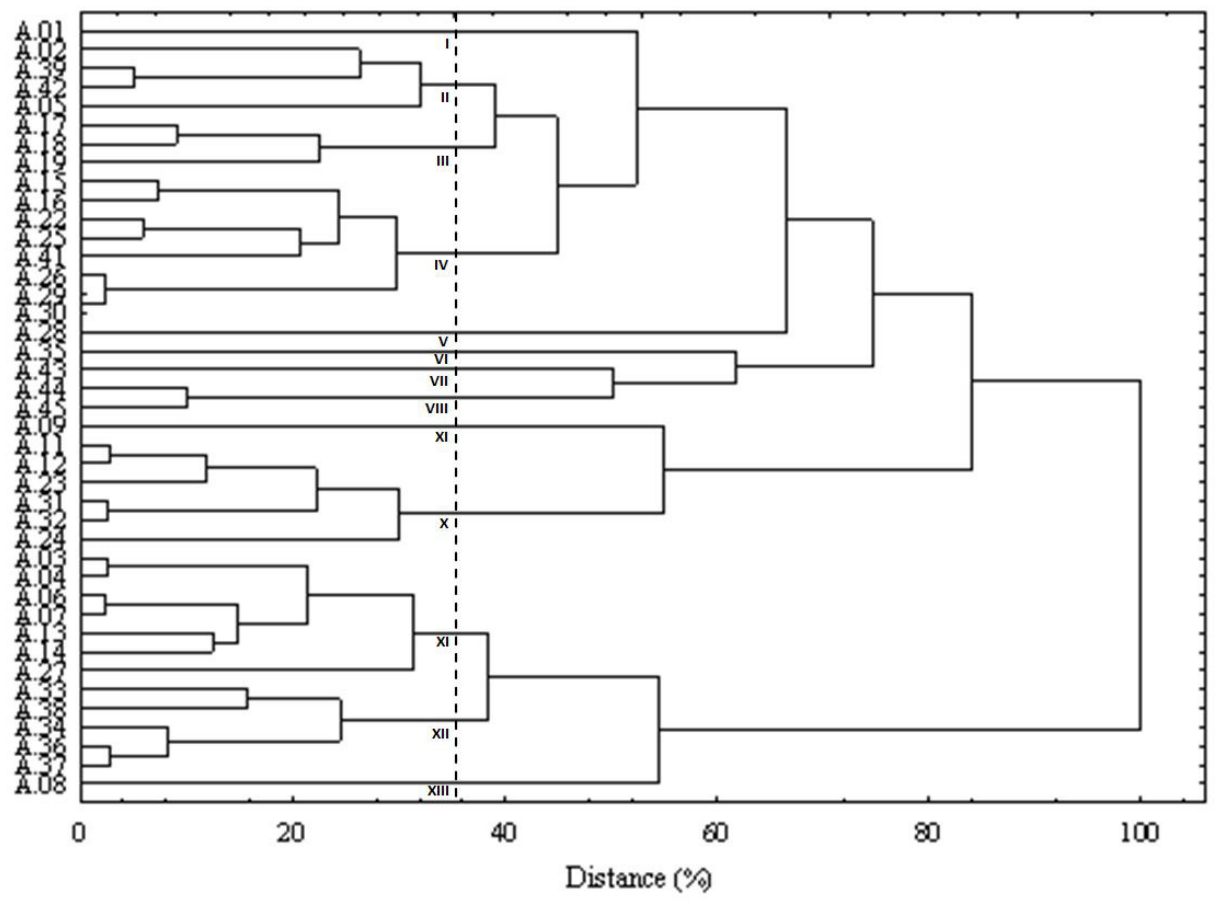

Figure 4. Cluster analysis of 41 accessions of melon by microsatellite markers calculated by the UPGMA clustering method using Nei's distance.

The second group was formed by accessions A-02 and A-39 (cantalupensis), A-42 (momordica), and A-05 (not defined). Accessions A-17 (conomon), A-18 (cantalupensis), and 
A-19 (not defined) formed the third group. The tenth group included accessions A-11 (conomon), A-12 (not defined), A-23 and A-32 (momordica), and A-24 and A-31 (cantalupensis). The eleventh group was predominated by accessions of cantalupensis (A-03, A-04, A-06, A-07, A-13, and A-14), and it also included accession A-27 (not defined). Finally, accessions A-33 (not defined), A-34 and A-36 (cantalupensis), and A-37 and A-38 (momordica) formed the twelfth group.

In the fourth group, it is interesting to note that the genetic distance between accessions A-29 (cantalupensis) and A-30 (momordica) was zero. This estimate is a consequence of the same banding pattern shown by both accessions for all polymorphic markers. This could be a typical case of double accessions; however, the plants are different and belong to different botanical groups. Therefore, the number of markers was not sufficient to separate them. The fourth group was the largest group, and it included accessions A-15 (momordica); A-16 (conomon); A-22, A-25, and A-41 (cantalupensis); and A-26 (not defined).

By the group formations, it can be observed that there was no association with the botanical classification of the accessions. The exceptions of this were the eighth group, which involved only two commercial hybrids, and the eleventh group, where six of the seven grouped accessions are of the botanical variety cantalupensis.

Staub et al. (2000) evaluated genetic diversity using random amplified polymorphic DNA (RAPD) and SSR and also grouped melons of the same botanical group in different groups along with accessions of other botanical groups. In contrast, 80 accessions of melon from different regions of the world were grouped according to the origin using 32 RAPD markers (Luan et al., 2008). Moreover, Garcia et al. (1998) used molecular markers and agronomic traits to perfectly group 32 strains according to seven different varieties.

Like the grouping based on fruit descriptors, the group made from microsatellite markers had a cophenetic value of $0.72(\mathrm{P}<0.01)$, which was considered appropriate for good agreement with the values of genetic similarity (Cruz and Carneiro, 2003).

Finally, although the molecular genetic divergence confirmed the large genetic variability, a high level of homozygosity was observed among accessions, which suggests that multiplication before collecting may promote changes in allelic frequencies in the evaluated germplasm.

\section{Comparison of similarity arrays}

By the Mantel test, the degree of association between the matrices of morphoagronomic and molecular genetic distances was null, considering that the estimate of the correlation (0.10) was not significant. In contrast, Garcia et al. (1998), who evaluated strains of seven different commercial types of melon, demonstrated a high correlation in the ability to detect genetic relationships between molecular markers and agronomic characteristics $(r=0.79)$. In cucumber, molecular markers were applied in the protection of plant varieties with a significant degree of association $(\mathrm{r}=0.65)$ between the dissimilarities based on molecular markers and morphological descriptors (Bernet et al., 2003). What may be considered for these two cases is the advanced degree of improvement of the evaluated genotypes.

However, some considerations explain the lack of correlation between genetic distance matrices in this study: 1) the morphoagronomic dendrogram formed eight groups while the molecular dendrogram formed 13 groups without relationships between the two dendrograms, including the botanical groups; 2) in the genetic divergence and morphoagronomic 
dendrograms, only descriptors of the fruit were considered, while microsatellites are distributed throughout the melon genome; 3 ) the evaluated descriptors are quantitative and the $17 \mathrm{SSR}$ markers are not sufficient to cover all regions of the genome responsible for the expression of these characteristics; 4) microsatellite markers are repetitive sequences and can be associated with regions of the genome that are not encoded and are not associated with the expression of any characteristic; 5) the SSR markers have no adaptive nature while the descriptors are under great environmental pressure; and 6) the uniform distribution of the 17 polymorphic microsatellite markers in genes responsible for expression of the nine quantitative descriptors of the fruit is an unlikely occurrence.

\section{CONCLUSIONS}

SSR molecular markers and morphoagronomic characteristics are effective tools to investigate diversity among melon accessions from traditional agriculture of the Brazilian Northeast. There is wide genetic variability among accessions, although there is no correlation between morphological and molecular data.

\section{REFERENCES}

Bernet GP, Bramardi S, Calvache D, Carbonell EA, et al. (2003). Applicability of molecular markers in the context of protection of new varieties of cucumber. Plant Breed. 122: 146-152.

Cruz CD (2013). GENES - a software package for analysis in experimental statistics and quantitative genetics. Acta Sci. Agron. 35: 271-276.

Cruz CD and Carneiro PCS (2003). Modelos Biométricos Aplicados ao Melhoramento Genético, UFV, Viçosa.

Deleu W, Esteras C, Roig C, González-To M, et al. (2009). A set of EST-SNPs for map saturation and cultivar identification in melon. BMC Plant Biol. 9: 90.

Djé Y, Tahi CG, Zoro Bi AI, Baudoin JP, et al. (2010). Use of ISSR markers to assess genetic diversity of African edible seeded Citrullus lanatus landraces. Sci. Hortic. 124: 159-164.

Escribano S and Lázaro A (2009). Agro-morphological diversity of Spanish traditional melons (Cucumis melo L.) of the Madrid provenance. Genet. Resour. Crop Evol. 56: 481-497.

Falconer DS (1981). Introdução à Genética Quantitativa, Universidade Federal de Viçosa, Viçosa.

FAO (Food and Agriculture Organization) (2013). Database FAOSTAT. Available at [http://faostat.fao.org]. Accessed March 30, 2013.

Fernández-Silva I, Moreno E, Eduardo I, Arus P, et al. (2009). On the genetic control of heterosis for fruit shape in melon (Cucumis melo L.). J. Hered. 100: 229-235.

Ferreira ME and Grattapaglia D (1998). Introdução ao Uso de Marcadores Moleculares em Análise Genética. 3rd edn. EMBRAPA-CENARGEN, Brasília.

Garcia E, Jamilena M, Alvarez JI, Arnedo T, et al. (1998). Genetic relationships among melon breeding lines revealed by RAPD markers and agronomic traits. Theor. Appl. Genet. 96: 878-885.

Hosoki T, Ishibashi A, Kitamura H, Kai N, et al. (1990). Classification of oriental melons based on morphological, ecological and physiological differences. J. Jpn. Soc. Hortic. Sci. 58: 959-970.

International Plant Genetic Resources Institute (2003). IPGRI; International Plant Genetic Resources Institute, Descriptors for Melon (Cucumis melo L.), Rome.

Kirkbride Jr JH (1993). Biosystematics Monograph of the Genus Cucumis (Cucurbitaceae): Botanical Identification of Cucumbers and Melons, Parkway Publishers, North Carolina.

Konopka J and Hanson J (1985). Information, Handling Systems for Genebank Management. IPGRI, Rome.

Liu K and Muse SV (2005). PowerMarker: an integrated analysis environment for genetic marker analysis. Bioinformatics 21: 2128-2129.

López-Sesé AI, Staub J, Katzir N and Gómez-Guillamón ML (2002). Estimation of between and within accession variation in selected Spanish melon germplasm using RAPD and SSR markers to assess strategies for large collection evaluation. Euphytica 127: 41-51. 
López-Sesé AI, Staub JE and Gomez-Guillamon ML (2003). Genetic analysis of Spanish melon (Cucumis melo L.) germplasm using a standardized molecular-marker array and geographically diverse reference accessions. Theor. Appl. Genet. 108: 41-52.

Luan F, Delannay I and Staub JE (2008). Chinese melon (Cucumis melo L.) diversity analyses provide strategies for germplasm curation, genetic improvement, and evidentiary support of domestication patterns. Euphytica 164: 445-461.

Mazzucato A, Ficcadenti N, Caioni M, Mosconi P, et al. (2010). Genetic diversity and distinctiveness in tomato (Solanum lycopersicum L.) landraces: the Italian case study of 'A pera Abruzzese'. Sci. Hortic. 125: 55-62.

McCreight JD, Nerson H and Grumet R (1993). Melon, Cucumis melo L. In: Genetic Improvement of Vegetable Crops (Kallos G and Bergh BO, eds.). Pergamon Press, New York, 267-294.

Monforte AJ, Oliver M, Gonzalo MJ, Alvarez JM, et al. (2004). Identification of quantitative trait loci involved in fruit quality traits in melon (Cucumis melo L.). Theor. Appl. Genet. 108: 750-758.

Monforte AJ, Eduardo I, Abad S and Arús P (2005). Inheritance mode of fruit traits in melon: heterosis for fruit shape and its correlation with genetic distance. Euphytica 144: 31-38.

Munger HM and Robinson RW (1991). Nomenclature of Cucumis melo L. Cucurbit Genet. Cooper. Rep. 14: 43-44.

Nakata E, Staub JE, López-Sesé AI and Katzir N (2005). Genetic diversity in Japanese melon (Cucumis melo L.) as assessed by random amplified polymorphic DNA and simple sequence repeat markers. Genet. Resour. Crop Evol. 52: 405-419.

Naudin CV (1859). Essais d'une monographie des espèces et des variétés du genre Cucumis. Ann. Sci. Nat. Bot. 11: 5-87.

Nei M (1972). Genetic distance between populations. Am. Nat. 106: 283-292.

Nunes GHS, Madeiros AES, Grangeiro LC, Santos GM, et al. (2006). Estabilidade fenotípica de híbridos de melão amarelo avaliados no Pólo agrícola Mossoró-Assú. Pesq. Agropec. Bras. 41: 1369-1376.

Paiva WO (2002). Divergência genética entre linhagens de melão e a heterose de seus híbridos. Hortic. Bras. 20: 34-37.

Paris MK, Zalapa JE, McCreight JD and Staub JE (2008). Genetic dissection of fruit quality components in melon (Cucumis melo L.) using a RIL population derived from exotic x elite US Western Shipping germplasm. Mol. Breed. 22: 405-419.

Queiróz MA (1993). Potencial do germoplasma de cucurbitáceas no Nordeste brasileiro. Hortic. Bras. 11: 7-9.

Ritschel PS, Lins TCL, Tristan RL, Buso GSC, et al. (2004). Development of microsatellite markers from an enriched genomic library for genetic analysis of melon (Cucumis melo L.). BMC Plant Biol. 4 : 9.

Singh D (1981). The relative importance of characters affecting genetic divergence. Indian J. Genet. Plant Breed. 41: 237-245.

Soltani F, Akashi Y, Kashi A, Zamani Z, et al. (2010). Characterization of Iranian melon landraces of Cucumis melo L. groups flexuosus and dudaim by analysis of morphological characters and random amplified polymorphic DNA. Breed. Sci. 60: 34-45.

Staub JE, Serquen FC and Gupta M (1996). Genetic markers, map construction and their application in plant breeding. HortScience 31: 729-741.

Staub JE, Danin-Poleg Y, Fazio G, Horejsi T, et al. (2000). Comparative analysis of cultivated melon groups (Cucumis melo L.) using random amplified polymorphic DNA and simple sequence repeat markers. Euphytica 115: 225-241.

Staub JE, López-Sesé AI and Fanourakis N (2004). Diversity among melon landraces (Cucumis melo L.) from Greece and their genetic relationships with other melon germplasm of diverse origins. Euphytica 136: 151-166.

Stepansky A, Kovalski I and Perl-Treves R (1999). Intraspecific classification of melons (Cucumis melo L.) in view of their phenotypic and molecular variation. Plant System. Evol. 217: 313-332.

Szabó Z, Gyulai G, Humphreys M, Horváth L, et al. (2005). Genetic variation of melon (C. melo) compared to an extinct landrace from the Middle Ages (Hungary) I. rDNA, SSR and SNP analysis of 47 cultivars. Euphytica 146: 87-94.

Szamosi C, Solmaz I, Sari N and Bársony C (2010). Morphological evaluation and comparison of Hungarian and Turkish melon (Cucumis melo L.) germplasm. Sci. Hortic. 124: 170-182.

Tantasawat P, Trongchuen J, Prajongjai T, Seehalak W, et al. (2010). Variety identification and comparative analysis of genetic diversity in yardlong bean (Vigna unguiculata spp. sesquipedalis) using morphological characters, SSR and ISSR analysis. Sci. Hortic. 124: 204-216. 